Brief report

\title{
Variables associated with insulin production in persons with type 2 diabetes treated with multiple daily insulin injections
}

\author{
Klara Westman a,b,*, Henrik Imberg ${ }^{c, d}$, Henrik Albrektsson ${ }^{\mathrm{c}}$, Irl B. Hirsch ${ }^{\mathrm{e}}$, \\ Jaakko Tuomilehto ${ }^{\mathrm{f}, \mathrm{g}, \mathrm{h}}$, Sofia Dahlqvist ${ }^{\mathrm{a}, \mathrm{b}}$, Marcus Lind ${ }^{\mathrm{a}, \mathrm{b}}$ \\ a Department of Medicine, NU-Hospital Group, Trollhättan/Uddevalla, Sweden \\ ${ }^{\mathrm{b}}$ Department of Molecular and Clinical Medicine, University of Gothenburg, Gothenburg, Sweden \\ ' Statistiska Konsultgruppen, Gothenburg, Sweden \\ d Department of Mathematical Sciences, Chalmers University of Technology and University of Gothenburg, Gothenburg, Sweden \\ e University of Washington School of Medicine, UW Medicine Diabetes Institute, Seattle, WA 98109, United States \\ ${ }^{\mathrm{f}}$ Public Health Promotion Unit, Finnish Institute for Health and Welfare, P.O. Box 30, 00271 Helsinki, Finland \\ ${ }^{g}$ Department of Public Health, University of Helsinki, 00014 Helsinki, Finland \\ ${ }^{\text {h }}$ Saudi Diabetes Research Group, King Abdulaziz University, 21589 Jeddah, Saudi Arabia
}

\section{A R T I C L E I N F O}

\section{Article history:}

Received 15 January 2020

Received in revised form 31 August 2020

Accepted 11 November 2020

Available online 7 December 2020

Keywords:

Type 2 diabetes mellitus

Multiple daily insulin injections

Insulin secretion

C-peptide and proinsulin and related

variables

\begin{abstract}
A B S T R A C T
From the MDI-liraglutide study, we evaluated variables associated with endogenous insulin production in persons with multiple daily insulin injections-treated type 2 diabetes by relating C-peptide, proinsulin and proinsulin/C-peptide ratio at baseline to baseline variables. Lower insulin production was related to longer diabetes duration, shorter abdominal sagittal diameter and more glycaemic variability.
\end{abstract}

(c) 2020 Primary Care Diabetes Europe. Published by Elsevier Ltd. All rights reserved.

\section{Introduction}

Type 2 diabetes (T2D) is a progressive disease with decreased insulin secretion in the later stages [1]. There are several treatment options to achieve good glycaemic control in these patients [2]. As a final step, when glycaemic control still does not meet target levels, multiple daily insulin injections (MDI) with basal and prandial insulin have been standard care approaches [3]. Endogenous insulin production exists for most persons in this population [4]. Insulin secretion is commonly measured by C-peptide [5], and the proinsulin/C-peptide ratio is used as a measurement of beta-cell dysfunction [6]. C-peptide levels have been associated with degree of diabetes complications and may have a biological importance [7-9].

Reduced endogenous insulin production likely leads to more fluctuating glucose levels and need of support with glucose-

\footnotetext{
* Corresponding author at: Department of Medicine, NU-Hospital Group, Trollhättan/Uddevalla, Sweden.

E-mail address: klawe165@student.liu.se (K. Westman).
}

stabilising treatments, including pharmacologic therapy and continuous glucose monitoring (CGM). Defining risk factors for reduced insulin secretion will increase the possibility for clinicians to identify patients in need of extra support. To our knowledge, there is a lack of contemporary studies of variables associated with low endogenous insulin secretion in persons with T2D treated with MDI. Additionally, studies investigating the association between insulin production and glycaemic variability using CGM data are scarce.

The aim of the current study was to increase the understanding of variables related to endogenous insulin production in persons with T2D treated with MDI.

\section{Methods}

The MDI-liraglutide study was approved by the Ethics Committee of the University of Gothenburg, Gothenburg, Sweden $\left(13^{\text {th }}\right.$ of November, 2012, diary number 596-12). The design and methods for the above-mentioned study has been described in detail elsewhere $[4,10]$. Briefly, it was a randomised, placebo-controlled, double-blind trial with a parallel group design conducted at 14 sites 
in Sweden. All participants granted written informed consent to participate.

\subsection{Screening}

The main inclusion criteria were persons clinically diagnosed with T2D and treated with MDI, HbA1c concentrations $\geq 58$ $\mathrm{mmol} / \mathrm{mol}(7.5 \%)$ and $\leq 102 \mathrm{mmol} / \mathrm{mol}$ (11.5\%), and fasting serum C-peptide level $\geq 0.1 \mathrm{nmol} / \mathrm{L}$.

\subsection{Run-in period and baseline characteristics}

After a run-in period of maximum eight weeks, with masked CGM (DexCom G4 PLATINUM, San Diego, CA) use for one week, baseline characteristics were measured. Serum C-peptide and proinsulin were measured in fasting condition and analysed at a central laboratory located at Karolinska University Hospital, Stockholm, Sweden.

\subsection{Endpoints}

In this study we evaluated C-peptide, proinsulin and proinsulin/C-peptide levels at baseline related to different baseline variables; fasting plasma glucose (FPG), age, sex, smoking, metformin use, glutamic acid decarboxylase (GAD) antibodies, diabetes duration, height, weight, BMI, abdominal sagittal diameter, hip circumference, waist circumference, waist/hip ratio, total daily basal insulin dose, total daily meal and basal insulin dose, HbA1c, CGM (mean and standard deviation (SD)), CGM coefficient of variation (CV), mean amplitude of glycaemic excursions (MAGE), systolic and diastolic blood pressure, and serum adiponectin levels. Subsequently, in an additional analysis, all variables were adjusted for the corresponding FPG level.

\subsection{Statistics}

Statistical analyses were performed using linear regression with the logarithm of C-peptide, proinsulin or proinsulin/C-peptide ratio as response variable, and the baseline variables described above as explanatory variables. The baseline variables were analysed one at a time in univariable (unadjusted) analyses and thereafter also adjusted for fasting plasma glucose by adding to the model fasting plasma glucose as a second explanatory variable. Exponentiated regression coefficients are presented with 95\% confidence intervals (CI), estimating the expected multiplicative change in C-peptide, proinsulin or proinsulin/C-peptide ratio per unit change in the explanatory variable. P-values $\leq 0.05$ were considered statistically significant.

All analyses were performed with SAS version 9.4 (Cary, North Carolina, USA).

\section{Results}

\subsection{Participants characteristics}

There were 124 participants randomised between February 2013 and February 2014, of whom 118 had information of Cpeptide levels and 119 had information of proinsulin levels for being included in the current analyses.

\subsection{Baseline variables in relation to C-peptide and proinsulin}

Lower C-peptide levels were associated with longer diabetes duration ( $p=0.028$ ), elevated GAD antibody levels $(p=0.028)$, shorter abdominal sagittal diameter $(p=0.013)$, shorter hip circumference $(p=0.033)$, shorter waist circumference $(p=0.040)$, greater glycaemic variability estimated by the SD with masked CGM ( $p<0.0001$ ), higher glycaemic variability measured by CV and MAGE $(p<0.0001)$, lower FPG ( $p<0.0001)$, higher systolic blood pressure $(p=0.039)$ and having never smoked $(p=0.011)$. The relation between $\mathrm{C}$-peptide levels and diabetes duration, abdominal sagittal diameter, CGM SD and FPG is illustrated in Fig. 1. Lower proinsulin levels were associated with longer diabetes duration ( $\mathrm{p}$ $=0.011)$, shorter abdominal sagittal diameter $(p=0.013)$, lower mean glucose level estimated by masked CGM ( $p=0.046)$, greater glycaemic variability estimated by the SD with masked CGM ( $\mathrm{p}=$ $<0.0001$ ), greater glycaemic variability measured by CV and MAGE $(\mathrm{p}<0.0001$ and $\mathrm{p}=0.001$, respectively), lower FPG $(\mathrm{p}<0.0001)$ and having never smoked $(\mathrm{p}=0.007)$. Lower proinsulin/C-peptide ratio levels were associated with older age $(p=0.001)$, longer diabetes duration ( $p=0.019)$, lower HbA1c ( $p=0.037)$, lower CGM mean glucose $(\mathrm{p}<0.001)$, greater glycaemic variability measured by CV $(\mathrm{p}<0.001)$, lower FPG $(\mathrm{p}=0.05)$, lower diastolic blood pressure $(\mathrm{p}$ $=0.001)$, and having never smoked $(p=0.033)$. Further results are presented in Table 1 , along with all variables being related to $\mathrm{C}$ peptide, proinsulin, and proinsulin/C-peptide ratio after adjusting for fasting plasma glucose.

\section{Discussion}

In this study of persons with T2D treated with MDI, lower insulin production estimated by C-peptide, proinsulin and proinsulin/Cpeptide ratio were associated with older age, elevated GAD antibody levels, longer diabetes duration, lower FPG, shorter abdominal sagittal diameter, smaller waist and hip circumference, greater glycaemic variability, lower glycaemic levels, lower systolic and diastolic blood pressure, and having never smoked.

Our findings are in line with previous research that depict higher C-peptide levels in persons with T2D with metabolic syndrome and higher BMI [7,9]. However, to our knowledge, there has not been any research on persons with type 2 diabetes treated with MDI as a subgroup, and furthermore it has not included CGM data.

The results in this study indicate that longer diabetes duration, shorter abdominal sagittal diameter and more glycaemic variability generally is associated with lower insulin production, both without and after adjusting for fasting plasma glucose. Reduced insulin production may lead to an increase in glucose fluctuations and therefore these patients are in greater need of glucose-stabilising treatments in clinical practise.

Whether persons with T2D should get support with more advanced glucose monitoring such as traditional continuous glucose monitor or Flash glucose monitor (FGM) is debated. Two major randomised trials on continuous glucose monitor/FGM in persons with T2D have shown inconsistent results: in the DIAMOND study HbA1c improved with $0.3 \%$ in the continuous glucose monitor group but hypoglycaemia incidence did not show any statistical significance, meanwhile Haak et al showed no difference in $\mathrm{HbA} 1 \mathrm{c}$ but reduced time in hypoglycaemia with approximately $43 \%$ with glucose sensing technology $[11,12]$. Our results indicate that degree of own insulin production is likely one of the most essential factors to determine whether continuous glucose monitor/FGM is needed as treatment for persons with T2D. These monitors can guide the patient and health care professionals to take actions to avoid excessive glucose fluctuations.

The current study indicates that both future trials and clinical practice should look at subgroups regarding need of continuous glucose monitor/FGM for glucose-stabilising effects and consider the level of endogenous insulin production. The strengths of the current study are the prospective design with data retrieved from a placebo controlled randomised clinical trial. The measurements of $\mathrm{C}$-peptide and proinsulin were made at a central laboratory 
Table 1

C-peptide and proinsulin values in relation to baseline characteristics variables in persons with type 2 diabetes treated with multiple daily insulin injections.

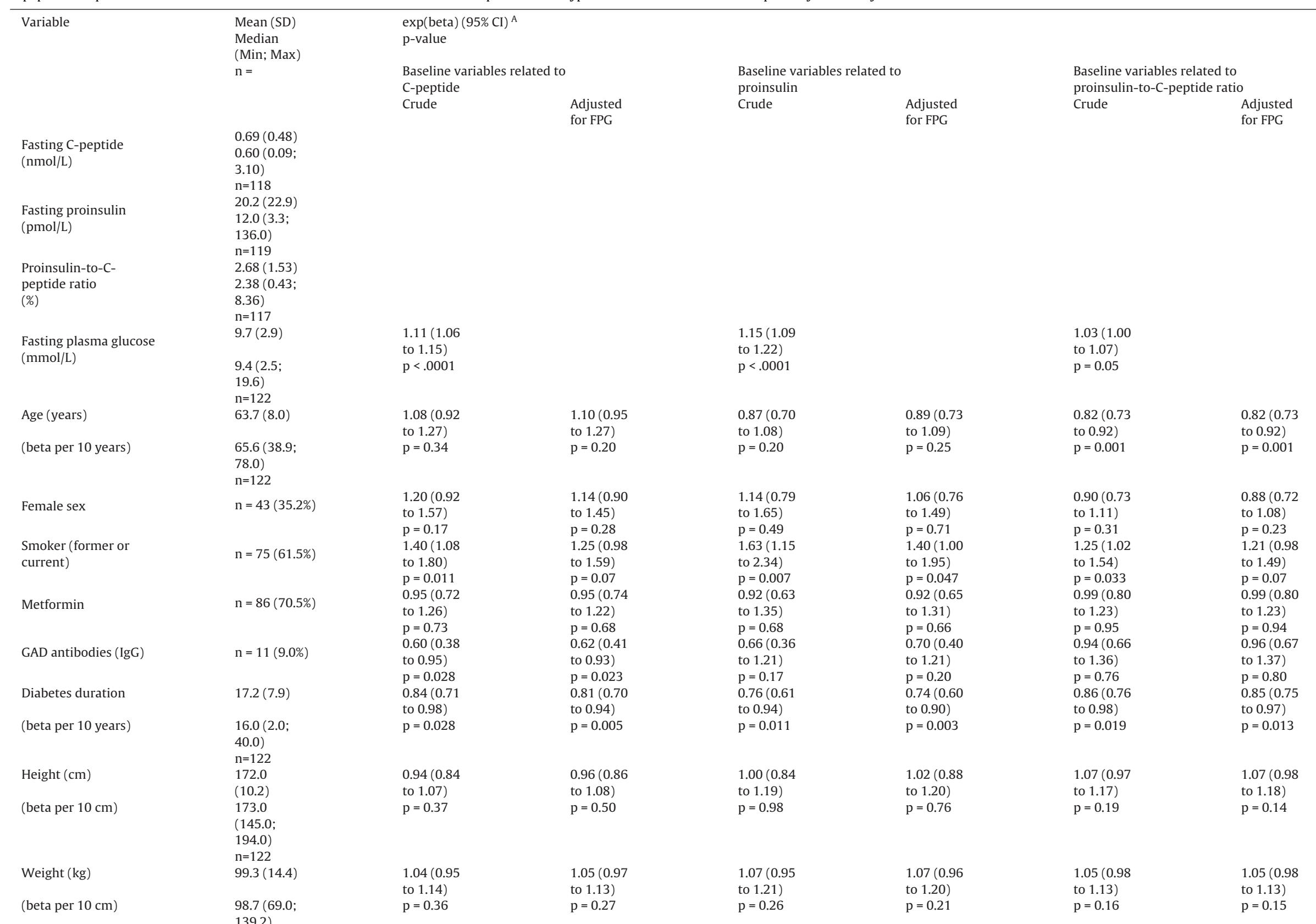

Baseline variables related to C-peptid

line variables related to proinsulin-to-C-peptide ratio 
Table 1 (Continued)

\begin{tabular}{|c|c|c|c|c|c|c|c|}
\hline $\operatorname{BMI}\left(\mathrm{kg} / \mathrm{m}^{2}\right)$ & $\begin{array}{l}33.6(4.1) \\
33.4(27.3 ; \\
44.0) \\
\mathrm{n}=122\end{array}$ & $\begin{array}{l}1.03(1.00 \\
\text { to } 1.06) \\
p=0.06\end{array}$ & $\begin{array}{l}1.03(1.00 \\
\text { to } 1.06) \\
\mathrm{p}=0.06\end{array}$ & $\begin{array}{l}1.03(0.98 \\
\text { to } 1.07) \\
\mathrm{p}=0.21\end{array}$ & $\begin{array}{l}1.02(0.98 \\
\text { to } 1.06) \\
\mathrm{p}=0.27\end{array}$ & $\begin{array}{l}1.00(0.98 \\
\text { to } 1.03) \\
\mathrm{p}=0.71\end{array}$ & $\begin{array}{l}1.00(0.98 \\
\text { to } 1.03) \\
\mathrm{p}=0.78\end{array}$ \\
\hline $\begin{array}{l}\text { Abdominal sagittal } \\
\text { diameter }(\mathrm{cm})\end{array}$ & $\begin{array}{l}27.8(3.5) \\
27.5(20.5 ; \\
36.9) \\
n=121\end{array}$ & $\begin{array}{l}1.05(1.01 \\
\text { to } 1.08) \\
p=0.013\end{array}$ & $\begin{array}{l}1.05(1.01 \\
\text { to } 1.08) \\
\mathrm{p}=0.010\end{array}$ & $\begin{array}{l}1.06(1.01 \\
\text { to } 1.13) \\
\mathrm{p}=0.013\end{array}$ & $\begin{array}{l}1.06(1.01 \\
\text { to } 1.11) \\
\mathrm{p}=0.015\end{array}$ & $\begin{array}{l}1.02(0.99 \\
\text { to } 1.05) \\
\mathrm{p}=0.16\end{array}$ & $\begin{array}{l}1.02(0.99 \\
\text { to } 1.05) \\
\mathrm{p}=0.18\end{array}$ \\
\hline $\begin{array}{l}\text { Hip circumference } \\
(\mathrm{cm}) \\
\text { (beta per } 10 \mathrm{~cm})\end{array}$ & $\begin{array}{l}112.2(9.5) \\
110.5 \\
(94.0 ; \\
139.0) \\
n=118\end{array}$ & $\begin{array}{l}1.16(1.01 \\
\text { to } 1.32) \\
p=0.033\end{array}$ & $\begin{array}{l}1.12(0.99 \\
\text { to } 1.27) \\
\mathrm{p}=0.07\end{array}$ & $\begin{array}{l}1.14(0.94 \\
\text { to } 1.38) \\
\mathrm{p}=0.17\end{array}$ & $\begin{array}{l}1.09(0.92 \\
\text { to } 1.30) \\
\mathrm{p}=0.33\end{array}$ & $\begin{array}{l}1.00(0.90 \\
\text { to } 1.12) \\
\mathrm{p}=0.99\end{array}$ & $\begin{array}{l}0.99(0.89 \\
\text { to } 1.10) \\
\mathrm{p}=0.88\end{array}$ \\
\hline $\begin{array}{l}\text { Waist } \\
\text { circumference } \\
(\mathrm{cm})\end{array}$ & $\begin{array}{l}115.9 \\
(10.3)\end{array}$ & $\begin{array}{l}1.14(1.01 \\
\text { to } 1.30)\end{array}$ & $\begin{array}{l}1.13(1.00 \\
\text { to } 1.27)\end{array}$ & $\begin{array}{l}1.17(0.98 \\
\text { to } 1.40)\end{array}$ & $\begin{array}{l}1.15(0.97 \\
\text { to } 1.35)\end{array}$ & $\begin{array}{l}1.06(0.95 \\
\text { to } 1.17)\end{array}$ & $\begin{array}{l}1.05(0.95 \\
\text { to } 1.16)\end{array}$ \\
\hline (beta per $10 \mathrm{~cm}$ ) & $\begin{array}{l}114.7 \\
(95.0 ; \\
144.8) \\
n=118\end{array}$ & $\mathrm{p}=0.040$ & $\mathrm{p}=0.041$ & $\mathrm{p}=0.07$ & $\mathrm{p}=0.10$ & $\mathrm{p}=0.28$ & $\mathrm{p}=0.32$ \\
\hline Waist-hip-ratio & $1.0(0.1)$ & $\begin{array}{l}1.00(0.81 \\
\text { to } 1.22)\end{array}$ & $\begin{array}{l}1.43(0.22 \\
\text { to } 9.44)\end{array}$ & $\begin{array}{l}1.07(0.81 \\
\text { to } 1.42)\end{array}$ & $\begin{array}{l}3.27(0.24 \\
\text { to } 43.91)\end{array}$ & $\begin{array}{l}1.11(0.95 \\
\text { to } 1.30)\end{array}$ & $\begin{array}{l}3.14(0.66 \\
\text { to } 15.06)\end{array}$ \\
\hline (beta per 0.1 units) & $\begin{array}{l}1.0(0.8 \\
1.2) \\
\mathrm{n}=117\end{array}$ & $\mathrm{p}=0.96$ & $p=0.70$ & $p=0.63$ & $p=0.37$ & $\mathrm{p}=0.20$ & $\mathrm{p}=0.15$ \\
\hline $\begin{array}{l}\text { Daily basal insulin } \\
\text { dose (units) } \\
\text { (beta per } 10 \text { units) }\end{array}$ & $\begin{array}{l}58.2(26.1) \\
56.0(12.0 \\
130.0) \\
n=122\end{array}$ & $\begin{array}{l}0.99(0.94 \\
\text { to } 1.04) \\
\mathrm{p}=0.60\end{array}$ & $\begin{array}{l}1.00(0.99 \\
\text { to } 1.00) \\
\mathrm{p}=0.73\end{array}$ & $\begin{array}{l}1.02(0.95 \\
\text { to } 1.08) \\
\mathrm{p}=0.65\end{array}$ & $\begin{array}{l}1.00(1.00 \\
\text { to } 1.01) \\
\mathrm{p}=0.54\end{array}$ & $\begin{array}{l}1.03(0.99 \\
\text { to } 1.06) \\
p=0.19\end{array}$ & $\begin{array}{l}1.00(1.00 \\
\text { to } 1.01) \\
\mathrm{p}=0.15\end{array}$ \\
\hline $\begin{array}{l}\text { Daily meal and } \\
\text { basal insulin } \\
\text { dose (units) }\end{array}$ & $\begin{array}{l}105.4 \\
(43.1)\end{array}$ & $\begin{array}{l}1.01(0.98 \\
\text { to } 1.04)\end{array}$ & $\begin{array}{l}1.00(0.98 \\
\text { to } 1.03)\end{array}$ & $\begin{array}{l}1.02(0.98 \\
\text { to } 1.07)\end{array}$ & $\begin{array}{l}1.02(0.98 \\
\text { to } 1.06)\end{array}$ & $\begin{array}{l}1.02(0.99 \\
\text { to } 1.04)\end{array}$ & $\begin{array}{l}1.02(0.99 \\
\text { to } 1.04)\end{array}$ \\
\hline (beta per 10 units) & $\begin{array}{l}100.0 \\
(28.0 ; \\
230.0) \\
n=122\end{array}$ & $\mathrm{p}=0.68$ & $\mathrm{p}=0.76$ & $\mathrm{p}=0.23$ & $\mathrm{p}=0.28$ & $\mathrm{p}=0.17$ & $\mathrm{p}=0.19$ \\
\hline $\begin{array}{l}\mathrm{HbA1c}(\mathrm{IFCC}) \\
(\mathrm{mmol} / \mathrm{mol})\end{array}$ & $74.5(11.4)$ & $\begin{array}{l}0.95(0.85 \\
\text { to } 1.06)\end{array}$ & $\begin{array}{l}0.84(0.76 \\
\text { to } 0.93)\end{array}$ & $\begin{array}{l}1.04(0.89 \\
\text { to } 1.21)\end{array}$ & $\begin{array}{l}0.88(0.76 \\
\text { to } 1.03)\end{array}$ & $\begin{array}{l}1.09(1.01 \\
\text { to } 1.20)\end{array}$ & $\begin{array}{l}1.07(0.98 \\
\text { to } 1.18)\end{array}$ \\
\hline $\begin{array}{l}\text { (beta per } 10 \\
\mathrm{mmol} / \mathrm{mol} \text { ) }\end{array}$ & $\begin{array}{l}73.0(53.0 \\
103.0)\end{array}$ & $\mathrm{p}=0.37$ & $\mathrm{p}=0.001$ & $\mathrm{p}=0.64$ & $\mathrm{p}=0.10$ & $\mathrm{p}=0.037$ & $\mathrm{p}=0.14$ \\
\hline
\end{tabular}


Table 1 (Continued)

\begin{tabular}{|c|c|c|c|c|c|c|c|}
\hline \multirow{3}{*}{ CGM mean (mmol/L) } & \multicolumn{7}{|l|}{$\mathrm{n}=122$} \\
\hline & $10.8(2.3)$ & $\begin{array}{l}1.00(0.94 \\
\text { to } 1.05)\end{array}$ & $\begin{array}{l}0.94(0.88 \\
\text { to } 0.99)\end{array}$ & $\begin{array}{l}1.08(1.00 \\
\text { to } 1.17)\end{array}$ & $\begin{array}{l}1.00(0.93 \\
\text { to } 1.09)\end{array}$ & $\begin{array}{l}1.08(1.04 \\
\text { to } 1.13)\end{array}$ & $\begin{array}{l}1.08(1.03 \\
\text { to } 1.13)\end{array}$ \\
\hline & $\begin{array}{l}10.3(5.7 \\
16.7) \\
\mathrm{n}=119\end{array}$ & $\mathrm{p}=0.91$ & $\mathrm{p}=0.019$ & $\mathrm{p}=0.046$ & $\mathrm{p}=0.92$ & $\mathrm{p}<.001$ & $\mathrm{p}=0.003$ \\
\hline \multirow[t]{2}{*}{ CGM SD $(\mathrm{mmol} / \mathrm{L})$} & $3.0(0.7)$ & $\begin{array}{l}0.61(0.53 \\
\text { to } 0.71)\end{array}$ & $\begin{array}{l}0.63(0.55 \\
\text { to } 0.72)\end{array}$ & $\begin{array}{l}0.62(0.50 \\
\text { to } 0.77)\end{array}$ & $\begin{array}{l}0.64(0.52 \\
\text { to } 0.78)\end{array}$ & $\begin{array}{l}0.97(0.84 \\
\text { to } 1.12)\end{array}$ & $\begin{array}{l}0.98(0.86 \\
\text { to } 1.13)\end{array}$ \\
\hline & $\begin{array}{l}2.8(1.6 \\
5.8) \\
\mathrm{n}=119\end{array}$ & $\mathrm{p}<.0001$ & $\mathrm{p}<.0001$ & $\mathrm{p}<.0001$ & $\mathrm{p}<.0001$ & $p=0.70$ & $\mathrm{p}=0.81$ \\
\hline CGM CV & $0.28(0.06)$ & $\begin{array}{l}0.57(0.48 \\
\text { to } 0.67)\end{array}$ & $\begin{array}{l}0.63(0.53 \\
\text { to } 0.76)\end{array}$ & $\begin{array}{l}0.44(0.35 \\
\text { to } 0.55)\end{array}$ & $\begin{array}{l}0.51(0.40 \\
\text { to } 0.65)\end{array}$ & $\begin{array}{l}0.77(0.66 \\
\text { to } 0.90)\end{array}$ & $\begin{array}{l}0.79(0.67 \\
\text { to } 0.93)\end{array}$ \\
\hline (beta per 0.1 units) & $\begin{array}{l}0.27(0.16 \\
0.45) \\
n=119\end{array}$ & $\mathrm{p}<.0001$ & $\mathrm{p}<.0001$ & $\mathrm{p}<.0001$ & $\mathrm{p}<.0001$ & $\mathrm{p}<.001$ & $\mathrm{p}=0.005$ \\
\hline \multirow[t]{2}{*}{ MAGE (mmol/L) } & $7.0(1.9)$ & $\begin{array}{l}0.84(0.79 \\
\text { to } 0.90)\end{array}$ & $\begin{array}{l}0.84(0.79 \\
\text { to } 0.89)\end{array}$ & $\begin{array}{l}0.85(0.77 \\
\text { to } 0.94)\end{array}$ & $\begin{array}{l}0.84(0.77 \\
\text { to } 0.92)\end{array}$ & $\begin{array}{l}0.98(0.93 \\
\text { to } 1.04)\end{array}$ & $\begin{array}{l}0.98(0.93 \\
\text { to } 1.04)\end{array}$ \\
\hline & $\begin{array}{l}6.7(3.5 ; \\
11.4) \\
n=108\end{array}$ & $\mathrm{p}<.0001$ & $\mathrm{p}<.0001$ & $\mathrm{p}=0.001$ & $\mathrm{p}<.001$ & $\mathrm{p}=0.58$ & $\mathrm{p}=0.54$ \\
\hline $\begin{array}{l}\text { Diastolic blood } \\
\text { pressure } \\
(\mathrm{mmHg})\end{array}$ & $74.2(10.9)$ & $\begin{array}{l}0.92(0.82 \\
\text { to } 1.03)\end{array}$ & $\begin{array}{l}0.89(0.80 \\
\text { to } 0.99)\end{array}$ & $\begin{array}{l}1.07(0.91 \\
\text { to } 1.26)\end{array}$ & $\begin{array}{l}1.04(0.89 \\
\text { to } 1.20)\end{array}$ & $\begin{array}{l}1.16(1.06 \\
\text { to } 1.26)\end{array}$ & $\begin{array}{l}1.15(1.05 \\
\text { to } 1.25)\end{array}$ \\
\hline $\begin{array}{l}\text { (beta per } 10 \\
\mathrm{mmHg} \text { ) }\end{array}$ & $\begin{array}{l}75(45 \\
103) \\
n=122\end{array}$ & $\mathrm{p}=0.15$ & $\mathrm{p}=0.034$ & $p=0.39$ & $p=0.62$ & $\mathrm{p}=0.001$ & $\mathrm{p}=0.002$ \\
\hline $\begin{array}{l}\text { Systolic blood } \\
\text { pressure } \\
(\mathrm{mmHg})\end{array}$ & $\begin{array}{l}135.9 \\
(15.5)\end{array}$ & $\begin{array}{l}0.91(0.84 \\
\text { to } 1.00)\end{array}$ & $\begin{array}{l}0.91(0.84 \\
\text { to } 0.98)\end{array}$ & $\begin{array}{l}0.92(0.82 \\
\text { to } 1.03)\end{array}$ & $\begin{array}{l}0.91(0.82 \\
\text { to } 1.01)\end{array}$ & $\begin{array}{l}1.00(0.94 \\
\text { to } 1.07)\end{array}$ & $\begin{array}{l}1.00(0.94 \\
\text { to } 1.06)\end{array}$ \\
\hline $\begin{array}{c}\text { (beta per } 10 \\
\mathrm{mmHg} \text { ) }\end{array}$ & $\begin{array}{l}136(101 ; \\
180)\end{array}$ & $\mathrm{p}=0.039$ & $\mathrm{p}=0.010$ & $\mathrm{p}=0.15$ & $\mathrm{p}=0.08$ & $\mathrm{p}=0.97$ & $\mathrm{p}=0.96$ \\
\hline \multirow[t]{2}{*}{ Adiponectin (mg/L) } & $4.4(2.2)$ & $\begin{array}{l}0.96(0.91 \\
\text { to } 1.02)\end{array}$ & $\begin{array}{l}0.97(0.92 \\
\text { to } 1.02)\end{array}$ & $\begin{array}{l}0.95(0.87 \\
\text { to } 1.03)\end{array}$ & $\begin{array}{l}0.95(0.89 \\
\text { to } 1.03)\end{array}$ & $\begin{array}{l}0.99(0.94 \\
\text { to } 1.04)\end{array}$ & $\begin{array}{l}0.99(0.95 \\
\text { to } 1.04)\end{array}$ \\
\hline & $\begin{array}{l}4.0(1.7 \\
15.0) \\
\mathrm{n}=121\end{array}$ & $\mathrm{p}=0.23$ & $\mathrm{p}=0.25$ & $\mathrm{p}=0.18$ & $\mathrm{p}=0.21$ & $\mathrm{p}=0.68$ & $\mathrm{p}=0.72$ \\
\hline
\end{tabular}



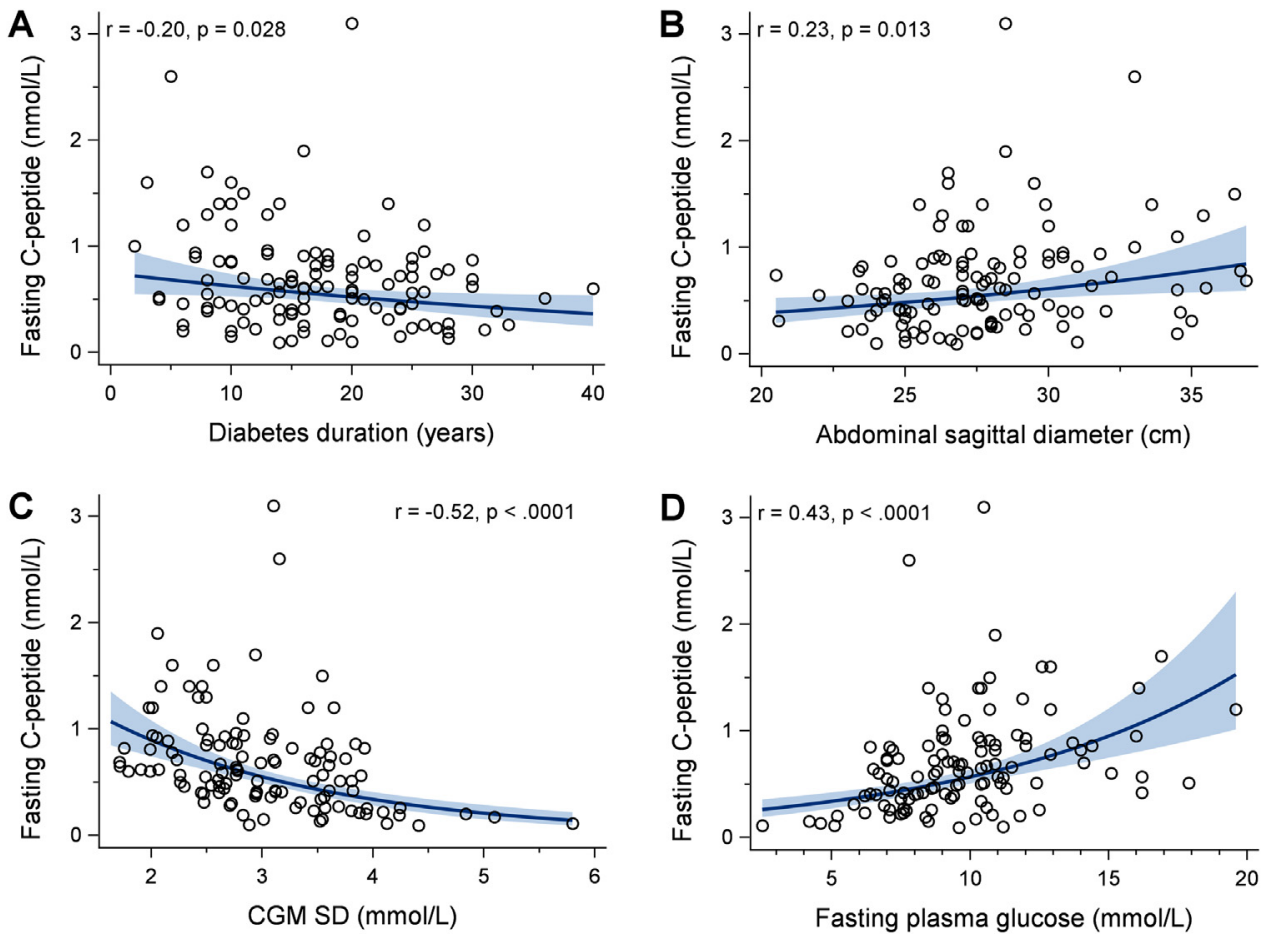

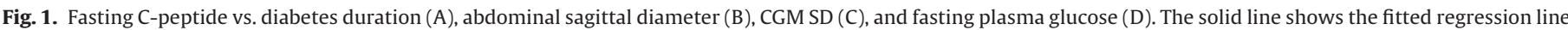

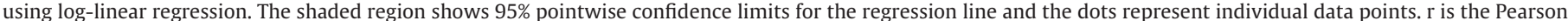
correlation coefficient with $\log (\mathrm{C}$-peptide).

and were both included in analyses regarding insulin secretion. A limitation of the study was the cross-sectional design. Also, measurement of insulin production can be made in a more accurate way using a glucose clamp or measuring C-peptide after a stimulation test.

In conclusion, persons with T2D treated with MDI with longer diabetes duration, shorter abdominal sagittal diameter and greater glycaemic variability have reduced insulin production and need extra focus for glucose-stabilising treatments.

\section{Funding}

The current study retrieved data from the MDI liraglutide trial, which was an investigator initiated trial, where Novo Nordisk provided financial support and study drugs but had no role in the design or execution of the trial; the interpretation, analysis, or publication of data; or the decision to submit the written report. NordicInfu Care provided continuous glucose monitoring systems and support. The current study was supported by grants from the Swedish government (under the Avtal om Läkarutbildning och medicinsk Forskning [agreement for medical education and research]).

\section{Conflicts of interest}

ML has received research grants from Dexcom and Novo Nordisk and been a consultant for Astra Zeneca, Boehringer Ingelheim, Dexcom, Eli Lily, MSD and Novo Nordisk.

IBH has received support from Medtronic and Insulet and has been consulting with Abbott Diabetes Care, Roche, and Bigfoot.

JT has received grants from Bayer Pharma, Boehringer Ingelheim and Merck outside the submitted work, and has acted as a consultant, advisory board member or speaker for Merck Serono, Orion Pharma, Renova and MSD, and owns shares in Orion Pharma. JT is the Editor-in-Chief of Primary Care Diabetes.

\section{Acknowledgement}

We want to thank everyone contributing to the MDI liraglutide trial which this study retrieved data from. Therefore, we thank the participants, the staff at participating care units, the local laboratories assisting in taking blood samples and logistics of laboratory transports, and the central laboratory; Gothia Forum for monitoring the trial and NordicInfu Care for training regarding masked continuous glucose monitoring and support with continuous glucose monitoring receivers; and Novo Nordisk for support with liraglutide and placebo and partly financing the MDI liraglutide trial.

\section{Appendix A. Supplementary data}

Supplementary material related to this article can be found, in the online version, at doi:https://doi.org/10.1016/j.pcd.2020.11. 005 .

\section{References}

[1] R.A. DeFronzo, Lilly lecture 1987. The triumvirate: beta-cell, muscle, liver. A collusion responsible for NIDDM, Diabetes 37 (1988) 667-687.

[2] American Diabetes Association, 9. Pharmacologic approaches to glycemic treatment: standards of medical care in diabetes-2019, Diabetes Care 42 (2019) 90-120.

[3] S.E. Inzucchi, R.M. Bergenstal, J.B. Buse, et al., Management of hyperglycaemia in type 2 diabetes: a patient-centered approach. Position statement of the American Diabetes Association (ADA) and the European Association for the Study of Diabetes (EASD), Diabetologia 55 (2012) 1577-1596.

[4] M. Lind, I.B. Hirsch, J. Tuomilehto, et al., Design and methods of a randomised double-blind trial of adding liraglutide to control HbA1c in patients with type 2 diabetes with impaired glycaemic control treated with multiple daily insulin injections (MDI-Liraglutide trial), Prim. Care Diabetes 9 (2015) 15-22.

[5] E. Leighton, C.A. Sainsbury, G.C. Jones, A practical review of C-peptide testing in diabetes, Diabetes Ther. 8 (2017) 475-487.

[6] E.K. Sims, Z. Chaudhry, R. Watkins, et al., Elevations in the fasting serum proinsulin-to-C-peptide ratio precede the onset of type 1 diabetes, Diabetes Care 39 (2016) 1519-1526. 
[7] Y. Wang, H. Wan, Y. Chen, et al., Association of C-peptide with diabetic vascular complications in type 2 diabetes, Diabetes Metab. (2019), http://dx.doi.org/10. 1016/j.diabet.2019.04.004.

[8] R. Sari, M.K. Balci, Relationship between C peptide and chronic complications in type-2 diabetes mellitus, J. Natl. Med. Assoc. 97 (2005) 1113-1118.

[9] T. Mavrakanas, C. Frachebois, A. Soualah, et al., C-peptide and chronic complications in patients with type-2 diabetes and the metabolic syndrome, Presse Med. 38 (2009) 1399-1403.

[10] M. Lind, I.B. Hirsch, J. Tuomilehto, et al., Liraglutide in people treated for type 2 diabetes with multiple daily insulin injections: randomised clinical trial (MDI Liraglutide trial), BMJ 351 (2015), h5364.
[11] R.W. Beck, T.D. Riddlesworth, K. Ruedy, et al., Continuous glucose monitoring versus usual care in patients with type 2 diabetes receiving multiple daily insulin injections: a randomized trial, Ann. Intern. Med. 167 (2017) 365-374.

[12] T. Haak, H. Hanaire, R. Ajjan, et al., Flash glucose-sensing technology as a replacement for blood glucose monitoring for the management of insulintreated type 2 diabetes: a multicenter, open-label randomized controlled trial Diabetes Ther. 8 (2017) 55-73. 